\title{
sciendo
}

CIVIL AND ENVIRONMENTAL ENGINEERING REPORTS

E-ISSN 2450-8594

CEER 2020; 30 (2): 0247-0257

DOI: $10.2478 /$ ceer-2020-0030

Original Research Article

\section{NITROGEN AND PHOSPHORUS CONTENT IN CONSTRUCTED WETLANDS}

\author{
Anita JAKUBASZEK ${ }^{1}$ \\ University of Zielona Góra, Institute of Environmental Engineering, Zielona Góra, \\ Poland
}

\begin{abstract}
High effectiveness of organic pollutants and nutrients removal is achieved in biological wastewater treatments plants - in case of proper exploitation of these objects. Nitrogen and phosphorus transformation or removal depends on many physic - chemical and biochemical conditions, deposit and environmental factors. A rule for treating wastewater consists in decomposition of organic compounds included in wastewater in water-soil environment. Removing contaminations is performed as a result of sorption of contaminations, bio-chemical oxidation-reduction reactions and biological activity of soil microorganisms and hydrophyte flora. The research has been carried out in the constructed wetland in Małyszyn (1300 EP). The treatment plant operates in horizontal system, with under-surface flow of wastewater.
\end{abstract}

Keywords: wastewater treatments, constructed wetland, nitrogen, phosphorus

\section{INTRODUCTION}

Constructed wetland systems are a representation of processes taking place in swamp ecosystems [5]. Habitat of water-liking plants is waterlogged grounds, characterised by hard existence conditions, mainly environments poor in oxygen [4]. Typical water-liking plants are, for example: common reed (Phragmites australis), sweet rush (Acorus calamus), reed meadow - grass (Glyceria

\footnotetext{
${ }^{1}$ Corresponding author: University of Zielona Gora, Institute of Environmental Engineering, Szafrana st. 15, 65-246 Zielona Góra, Poland; e-mail: A.Jakubaszek@iis.uz.zgora.pl
} 
aquatica), catails (Typha latifolia) etc.[13,14]. These objects are mainly used for cleaning wastewater from rural areas and dispersed facilities, characterised with small daily amount of wastewater [9, 3]. In constructed wetland systems wastewater treatment takes place with assistance of macrophyte flora.

A rule for treating wastewater consists in decomposition of organic compounds included in wastewater in water-soil environment. Removing contaminations is performed as a result of sorption of contaminations, bio-chemical oxidationreduction reactions and biological activity of soil microorganisms and hydrophyte flora [6].

The role of the plants consists in assisting the processes of treating wastewater by following means [13]:

- transport of oxygen from surface part to root part;

- loosening the structure of soil with roots and keeping good permeability;

- intake of nutrient substances and water by plants.

Characteristic feature of macrophyte plants is the fact of having aerenchyma, surface tissue enabling functioning of these plants in unfavourable conditions. Aerenchyma present in the whole of the plant enables transport of oxygen from the parts above the ground to organs staying under water. Thus the whole plant is provided in oxygen. The oxygen, as a result of diffusion, penetrates neighbouring soil, which creates a zone rich in oxygen around the roots; the bigger the distance, the smaller amount of oxygen. This way a mosaic of oxygen and non-oxygen zones is created, inhabited by different sorts of microorganisms - bacteria, mushrooms, algae and protozoa $[1,2,7]$.

A developed system of rhizomes and roots of macrophytes spreading in the ground has positive influence on uniform soaking of wastewater and enables the plants an intensive growth. Big increase of biomass is linked with intensive transpiration of water from the system to atmosphere and with accumulation of nitrogen and phosphor in tissues of the plants. Necrosing roots and rhizomes decompose, leaving cylindrical spaces and channels, increasing and stabilising hydraulic conductivity of the filter [8].

There exist considerable differences in taking macro- and microelements by individual species of macrophytes. The most of nitrogen is accumulated in tissues of mielec manna (Glyceria maxima), the most phosphorus - sweet rush (Acorus calamus). The poorest in nitrogen are tissues of bulrush (Schoenoplectus lacustrii), in phosphorus - tissues of common reed (Phragmites austrialis). Differences in accumulation of elements are observed not only in different species but also in different parts of plants of the same species. Leaves of common reed may contain up to $3.50 \%$ of nitrogen dry mass and $0.15 \%$ of phosphorus dry mass, whereas their stems respectively $0.90 \%$ of 
nitrogen and $0.08 \%$ of phosphorus in dry mass [10]. The capacity of accumulating phosphorus in macrophyte plants is considerably lower compared to obtained nitrogen. Maximum contents of biogenic elements in macrophyte flora is presented in a table 1.

Table 1. Maximum contents of biogenic elements in different parts of macrophyte plants [10]

\begin{tabular}{|l|l|c|c|}
\hline \multicolumn{1}{|c|}{ Species } & \multicolumn{1}{|c|}{ Parts of plants } & $\mathrm{N}[\%$ in dry mass] & $\mathrm{P}[\%$ in dry mass] \\
\hline \multirow{2}{*}{$\begin{array}{l}\text { Common } \\
\text { Reed }\end{array}$} & Leaves & 3.50 & 0.15 \\
\cline { 2 - 4 } & Stem & 0.90 & 0.08 \\
\cline { 2 - 4 } & Underground part & 1.50 & 0.18 \\
\hline \multirow{3}{*}{ Catails } & Leaves & 2.86 & 0.45 \\
\cline { 2 - 4 } & Stem & 1.30 & 0.43 \\
\cline { 2 - 4 } & Underground part & 2.47 & 0.72 \\
\hline \multirow{3}{*}{$\begin{array}{l}\text { Rweet rush } \\
\text { grass }\end{array}$} & Leaves & 3.71 & 0.90 \\
\cline { 2 - 4 } & Stem & 1.50 & 0.50 \\
\cline { 2 - 4 } & Underground part & 1.60 & 0.88 \\
\hline \multirow{2}{*}{ meadow -} & Leaves & 4.60 & 0.80 \\
\cline { 2 - 4 } & Stem & 2.94 & 0.42 \\
\cline { 2 - 4 } & Underground part & 4.45 & 1.05 \\
\hline
\end{tabular}

Phosphorus in swamp ecosystem circulates between water-soil and the plant. The plants take in phosphorus with their roots and accumulate it in overground parts. When the plants starts to die, considerable part of phosphorus deposed in overground part is transported to the roots and rhizomes, where it is stored [12]. It is estimated that $45 \%$ of phosphorus is returned to underground parts of the plants. Dead plant parts staying on the surface of the soil decompose (both oxygen and non-oxygen decomposition), depending on the conditions. Part of the dead biomass that has not been decomposed forms a new layer of the soil. It leads to durable keeping of phosphorus and other substances in the ecosystem [11].

\section{MATERIAL AND METHODS}

The research has been carried out in the constructed wetland in Małyszyn, built in 1993 and servicing $1300 \mathrm{EP}$. The treatment plant operates in horizontal system, with under-surface flow of wastewater ( $\mathrm{HF}-\mathrm{CW})$. The surface of the root system is of $3800 \mathrm{~m}^{2}$ and is seeded with common reed (Fig. 1). The plant is designed to treat household wastewater from the town of Małyszyn. In accordance with design assumptions the root pond's bottom and its slopes are to be sealed using clay. Arrangement of sealing layers is the following: 
- clay layer of thickness of $40 \mathrm{~cm}$,

- gravel and boulders layer of thickness of $40 \mathrm{~cm}$,

- soil and sand layer of thickness of $40 \mathrm{~cm}$.

The layer of rich soil mixed with sand $(1: 1)$ was the base for reed rooting. Household wastewater from the locality of Małyszyn after mechanical treatment in the sedimentation tank is directed to the distribution chamber located upstream the root system and next through a perforated pipe wastewater is uniformly distributed on entire width of the macrophyte deposit.

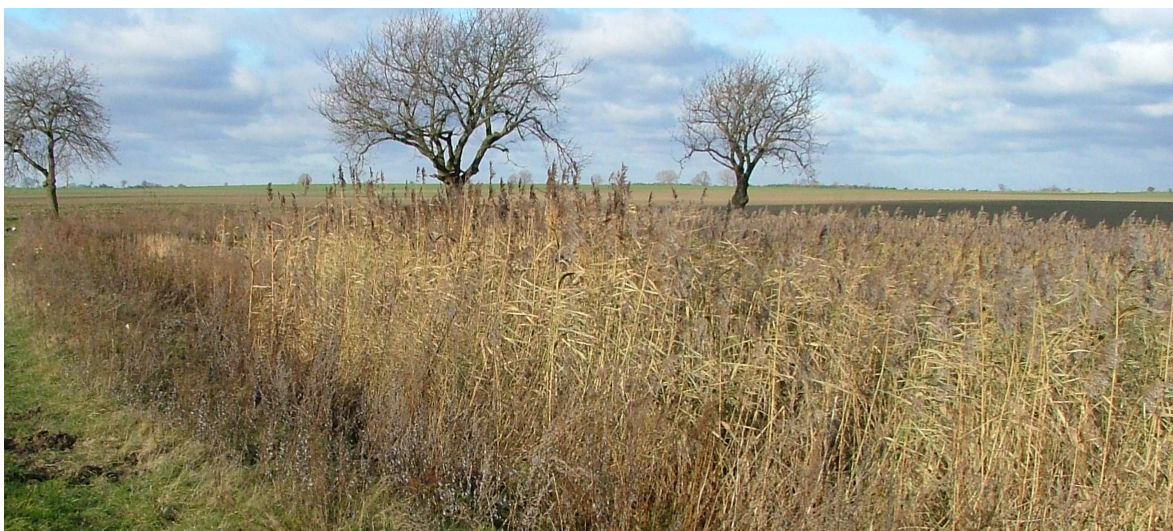

Fig. 1. Constructed wetland in Małyszyn

Samples for tests were taken in summer, autumn and in winter. Wastewater was sampled on the inflow to macrophyte - based deposit and on the outflow to the treatment plant. On the start of the plant, in the middle and on the outflow from constructed wetland a slice of the deposit was taken as well as macrophyte plant. Soil samples were taken from three levels: $20 \mathrm{~cm}, 20-40 \mathrm{~cm}$ and 40-60 cm under surface. In each selected point were taken 4 primary samples next joined making one general sample. In order to prepare a laboratory sample the general sample was located on a plastic tray next thoroughly mixed in order to obtain average content, plant parts and other solid contaminations were removed. Samples in this way prepared were dried to air dry state, next crushed in a mortar and screened using a sieve with mesh size of $2 \mathrm{~mm}$.

The plants taken for tests were divided to leaves, stem, root and inflorescence. The dried sample of plant material was crushed in a mill to size of approx. $1 \mathrm{~mm}$ (a sieve with size of square mesh of $1 \mathrm{~mm}$ ). Averaged by 10-times mixing sample was located in plastic container and next hermetically closed.

Mineralisation of plant and soil material was made in sulphuric acid and hydrogen peroxide environment, using Digesdahl mineralization column.

In raw and treated wastewater the following denotations were made: 
- Total Kjeldahl nitrogen (using titrimetric method; using Vapodest apparatus made by C. Gerhardt company);

- Total phosphorus (colorimetric method, using ammonium molybdate). In deposit samples and in plant parts the following was denoted:

- Total nitrogen (using titrimetric method; using Vapodest apparatus made by C. Gerhardt company);

- Total phosphorus (Komprath's colorimeric method, with vanadium molybdenum mix).

\section{RESULTS AND DISSCUSION}

The results of the tests concerning the concentration of total nitrogen and phosphorus in raw and treated wastewater in particular seasons were set up in a table 2.

Table 2. Concentration of nitrogen and phosphorus in wastewater

\begin{tabular}{|c|c|c|c|c|c|c|c|}
\hline \multirow{2}{*}{$\begin{array}{c}\text { Parameter } \\
{[\mathrm{mg} / \mathrm{l}]}\end{array}$} & \multicolumn{6}{|c|}{ SPRING } & \multicolumn{2}{c|}{ AUTUMN } & \multicolumn{2}{c|}{ WINTER } \\
\cline { 2 - 8 } & $\begin{array}{c}\text { raw } \\
\text { wastewater }\end{array}$ & $\begin{array}{c}\text { treated } \\
\text { wastewater }\end{array}$ & $\begin{array}{c}\% \\
\text { removal }\end{array}$ & $\begin{array}{c}\text { raw } \\
\text { wastewater }\end{array}$ & $\begin{array}{c}\text { treated } \\
\text { wastewater }\end{array}$ & $\begin{array}{c}\text { raw } \\
\text { wastewater }\end{array}$ & $\begin{array}{c}\text { treated } \\
\text { wastewater }\end{array}$ \\
\hline $\begin{array}{c}\text { Total } \\
\text { nitrogen }\end{array}$ & 54.6 & 1.4 & $\mathbf{9 7}$ & 14.0 & 49.0 & 46.2 & 70.0 \\
\hline $\begin{array}{c}\text { Total } \\
\text { phosphorus }\end{array}$ & 19.1 & 4.1 & $\mathbf{7 9}$ & 7.7 & 16.0 & 3.2 & 12.6 \\
\hline
\end{tabular}

In spring good work results were obtained in the plant, confirmed with high efficiency of removing biogenic compounds. In autumn-winter period concentration of nitrogen and phosphorus in treated wastewater was higher compared to concentration in raw wastewater. This indicates washing away biogenic compounds from macrophyte deposit. These results show great divergence in removal of biogenic compounds in Małyszyn wastewater treatment plant [9].

\section{CONTENTS OF NITROGEN IN CONSTRUCTED WETLAND}

Contents of general nitrogen in reed and in the deposit of HF - CW during different seasons are presented in a tables. The results indicate that during summer the reed accumulates similar amounts of nitrogen, regardless of the place of planting (table 3). Contents of nitrogen in leaves is about $3.50 \%$ to 3.91 $\%$ in dry mass, $1.68-2.10 \%$ in stem of nitrogen in dry mass, and in root system $-1.26 \%$ to $1.43 \%$. 
The results of the tests regarding contents of general nitrogen in the deposit of $\mathrm{HF}-\mathrm{CW}$ show that the highest concentrations take place in the layer up to 20 $\mathrm{cm}$ of depth, especially in the first part of the plot. Small amounts of general nitrogen penetrate to the layer $20-40 \mathrm{~cm}$, nitrogen penetration inside the plot increases in the direction of wastewater outflow.

Table 3. Contents of general nitrogen in reed and in the deposit of constructed wetlands plot in summer (July)

\begin{tabular}{|c||c|c|c|c|}
\hline \multicolumn{2}{|c|}{$[\%]$ in dry mass } & INFLOW & MIDDLE & OUTFLOW \\
\hline \multirow{3}{*}{$\begin{array}{c}\text { Common } \\
\text { Reed }\end{array}$} & Inflorescence & not tested & not tested & not tested \\
\cline { 2 - 5 } & Leaves & 3.71 & 3.91 & 3.50 \\
\cline { 2 - 5 } & Stem & 2.10 & 1.68 & 1.79 \\
\cline { 2 - 5 } & Root & 1.26 & 1.43 & 1.37 \\
\hline \hline \multirow{2}{*}{$\begin{array}{c}\text { Levels } \\
\text { wetland } \\
\text { system }\end{array}$} & $0-20$ & 2.31 & 0.66 & 1.12 \\
\cline { 2 - 5 } & $20-40$ & 0.04 & 0.06 & 0.93 \\
\hline
\end{tabular}

During autumn the highest concentration of nitrogen occur in leaves and inflorescence of reed (table 4). The concentrations oscillate around 2.23 to 3.87 $\%$ of nitrogen in dry mass. The amount of nitrogen in leaves is only a bit lower than during summer. However, a considerable drop of nitrogen in the stem is observed as well as increase in its contents in underground part of the plant.

Table 4. Contents of general nitrogen in reed and in the deposit of constructed wetlands plot in autumn

\begin{tabular}{|c||c|c|c|c|}
\hline \multicolumn{2}{|c|}{$\mathrm{N}[\%]$ in dry mass } & INFLOW & MIDDLE & OUTFLOW \\
\hline \multirow{3}{*}{$\begin{array}{c}\text { Common } \\
\text { Reed }\end{array}$} & Inflorescence & 2.57 & 2.56 & 2.23 \\
\cline { 2 - 5 } & Leaves & 2.66 & 3.87 & 2.66 \\
\cline { 2 - 5 } & Stem & 0.91 & 0.69 & 0.84 \\
\cline { 2 - 5 } & Root & 1.58 & 2.29 & 1.03 \\
\hline \hline \multirow{2}{*}{$\begin{array}{c}\text { Levels } \\
\text { wetland } \\
\text { system }\end{array}$} & $0-20$ & 2.21 & 2.27 & 0.72 \\
\cline { 2 - 5 } & $20-40$ & 0.08 & 0.52 & 0.73 \\
\cline { 2 - 5 } & $40-60$ & 0.04 & 0.04 & 0.71 \\
\hline
\end{tabular}

In the autumn nitrogen penetrates to deeper parts of the deposit in summer period. In the layer $40-60 \mathrm{~cm}$ on the start of the plot its contents is about 0.04 $\%$ of dry mass. In the end part it is distributed uniformly in the whole depth and is around 0.71 to $0.73 \%$ of dry mass. 
During winter a further drop is observed in contents of general nitrogen in leaves, stem and underground parts of reed, as for the inflorescence it is kept on a level similar o that during autumn (table 5). Reed leaves have from 1.19 to $2.82 \%$ of nitrogen in dry mass, stem from 0.63 to $0.79 \%$, the roots from 1.05 to $1.51 \%$ of this element in dry mass.

Table 5. Contents of general nitrogen in reed and in the deposit of constructed wetlands plot in winter (February)

\begin{tabular}{||c|c|c|c|c||}
\hline \hline \multicolumn{2}{|c|}{$[\%]$ in dry mass } & INFLOW & MIDDLE & OUTFLOW \\
\hline \multirow{3}{*}{$\begin{array}{c}\text { Common } \\
\text { Reed }\end{array}$} & Inflorescence & 1.75 & 2.21 & 2.68 \\
\cline { 2 - 5 } & Leaves & 1.75 & 2.82 & 1.19 \\
\cline { 2 - 5 } & Stem & 0.77 & 0.79 & 0.63 \\
\cline { 2 - 5 } & Root & 1.51 & 1.48 & 1.05 \\
\hline \hline Levels & $0-20$ & 1.90 & 0.80 & 0.97 \\
\cline { 2 - 5 } wetland & $20-40$ & 1.50 & 0.59 & 0.80 \\
\cline { 2 - 5 } system & $40-60$ & 1.63 & 0.13 & 0.84 \\
\hline
\end{tabular}

During non-vegetation period of plants, compounds of nitrogen reach the higher degree of penetration inside of macrophyte deposit. In the layer $40-60 \mathrm{~cm}$ the concentration of total nitrogen are oscillate around 0.13 to $1.63 \%$ of dry mass.

\section{CONTENTS OF TOTAL PHOSPHORUS IN MACROPHYTE DEPOSIT}

The results of tests concerning contents of phosphorus in the soil and macrophyte flora of the treatment plant in Małyszyn are presented in a tables 6, 7 and 8 . In summer (table 6) reed leaves have from 0.26 to $0.28 \%$ of fhosphorus in dry mass, stem from 0.21 to $0.25 \%$, the roots from 0.19 to $0.28 \%$ of this element in dry mass. During summer one observes similar values of total phosphorus in the plants, regardless of the place of planting. 
Table 6. Contents of total phosphorus in reed and in the deposit of constructed wetlands in summer (July)

\begin{tabular}{|c||c|c|c|c|}
\hline \multicolumn{2}{|c|}{$[\%]$ in dry mass } & INFLOW & MIDDLE & OUTFLOW \\
\hline \multirow{3}{*}{$\begin{array}{c}\text { Common } \\
\text { Reed }\end{array}$} & Inflorescence & not tested & not tested & not tested \\
\cline { 2 - 5 } & Leaves & 0.26 & 0.28 & 0.27 \\
\cline { 2 - 5 } & Stem & 0.25 & 0.21 & 0.25 \\
\hline \hline \multirow{2}{*}{$\begin{array}{c}\text { Levels } \\
\text { wetland } \\
\text { system }\end{array}$} & $0-20$ & 0.19 & 0.28 & 0.20 \\
\cline { 2 - 5 } & $20-40$ & 0.17 & 0.04 & 0.03 \\
\cline { 2 - 5 } & $40-60$ & 0.02 & 0.02 & 0.04 \\
\hline
\end{tabular}

In the summer the highest concentration of phosphorus in the soil $(0.17 \%$ in dry mass) occurs in the first part of bed in the layer to $20 \mathrm{~cm}$. During vegetation season of the plants a small presentation of phosphorus inside the plot occurs. In the layer $20-40 \mathrm{~cm}$ the concentration of total phosphorus are oscillate around 0.02 to $0.04 \%$ of dry mass.

During autumn the amount of phosphorus in stems of reed drops to about 0.14 $0.17 \%$ in dry mass (table 7). Contents of this element in leaves and roots of the plant does not change compared with summer period.

Table 7. Contents of total phosphorus in reed and in the deposit of constructed wetlands in autumn (October)

\begin{tabular}{||c||c|c|c|c|}
\hline \hline \multicolumn{2}{|c|}{$[\%]$ in dry mass } & INFLOW & MIDDLE & OUTFLOW \\
\hline \multirow{3}{*}{$\begin{array}{c}\text { Common } \\
\text { Reed }\end{array}$} & Inflorescence & 0.57 & 0.37 & 0.36 \\
\cline { 2 - 5 } & Leaves & 0.28 & 0.28 & 0.23 \\
\cline { 2 - 5 } & Stem & 0.17 & 0.15 & 0.14 \\
\cline { 2 - 5 } & Root & 0.23 & 0.28 & 0.25 \\
\hline \hline \multirow{2}{*}{$\begin{array}{c}\text { Levels } \\
\text { wetland } \\
\text { system }\end{array}$} & $0-20$ & 0.57 & 0.75 & 0.15 \\
\cline { 2 - 5 } & $20-40$ & 0.05 & 0.17 & 0.16 \\
\hline \multicolumn{2}{|l|}{} \\
\cline { 2 - 5 }
\end{tabular}

In the autumn the test results concerning contents of total phosphorus in HF CF show that the highest concentrations $0.57-0.75 \%$ of dry mass occur in the layer to $20 \mathrm{~cm}$ depth, especially in the first part of the plot. In the bed phosporus penetrates to deeper parts of the deposit in summer period. 
During winter (table 8) a further drop of total phosphorus contents in the stem of the plant. The inflorescence of reed contains $0.26-0.41 \%$ of phosphorus in dry mass, leaves $0.18-0.35 \%$ and underground parts $0.22-0.35 \%$.

Table 8. Contents of total phosphorus in reed and in the deposit of constructed wetlands in winter (February)

\begin{tabular}{|c||c|c|c|c||}
\hline \multicolumn{2}{|c|}{$[\%]$ in dry mass } & INFLOW & MIDDLE & OUTFLOW \\
\hline \multirow{3}{*}{$\begin{array}{c}\text { Common } \\
\text { Reed }\end{array}$} & Inflorescence & 0.26 & 0.41 & 0.31 \\
\cline { 2 - 5 } & Leaves & 0.24 & 0.35 & 0.18 \\
\cline { 2 - 5 } & Stem & 0.13 & 0.13 & 0.13 \\
\cline { 2 - 5 } & Root & 0.35 & 0.22 & 0.28 \\
\hline \multirow{2}{*}{$\begin{array}{c}\text { Levels } \\
\text { wetland } \\
\text { system }\end{array}$} & $0-20$ & 0.80 & 0.26 & 0.18 \\
\cline { 2 - 5 } & $20-40$ & 0.70 & 0.27 & 0.17 \\
\cline { 2 - 5 } & $40-60$ & 0.71 & 0.13 & 0.16 \\
\hline
\end{tabular}

The test results concerning contents of total phosphorus in constructed wetlands show uniform penetration on the whole depth of the deposit. In the first part of the treatment plant the concentration of phosphorus are shaped on level $0.70-$ $0.80 \%$ of dry mass and after outflow - from 0.16 to $0.18 \%$ of dry mass.

\section{CONCLUSIONS}

The following results from the tests:

- the most nitrogen and phosphorus is accumulated in inflorescence and leaves of the plant, then in roots and the least in the stems.

- during summer (plant vegetation) reed accumulates similar amounts of nitrogen and phosphorus, regardless of the place of planting;

- in macrophyte deposit the highest concentration of general nitrogen and phosphorus is observed in the first part of the deposit in the layer to 20 $\mathrm{cm}$, and the penetration of these elements increases towards the direction of the outflow from the plant;

- during the period of plant vegetation small penetration of nitrogen and phosphorus is observed inside macrophyte deposit;

- during winter nitrogen and phosphorus compounds reach the highest degree of penetration inside macrophyte deposit. 


\section{REFERENCES}

1. Brix, H., 1993. Macrophyte-mediated oxygen transfer in wetlands: transport mechanisms and rates. In Moshiri, A. G. (ed.), Constructed Wetlands for Water Quality Improvement. CRC Press, Boca Raton, FL: 391-398.

2. Brix, H., 2003. Plants used in constructed wetlands and their functions. In Dias, V. \& J. Vymazal (eds), Proceedings of Conference on the Use of Aquatic Macrophytes for Wastewater Treatment in Constructed Wetlands. ICN and INAG, Lisbon: 81-109.

3. Bydałek, F and Myszograj, S 2019. Safe surface concept in vertical flow constructed wetland design to mitigate infection hazard. Journal of Environmental Science and Health, Part A, 1-10.

4. Jakubaszek, A and Sadecka, Z 2015. The effectiveness of organic pollutants removal in constructed wetland with horizontal sub-surface flow. Civil and environmental engineering reports 16, 69-82.

5. Jakubaszek, A and Stadnik, A 2018. Technical and technological analysis of individual wastewater treatment systems. Civil and Environmental Engineering Reports 28 (1), 87-99.

6. Jakubaszek, A and Wojciech, M 2014. Statistical analysis of nitrogen in the soil of constructed wetland with horizontal sub-surface flow. Civil and Environmental Engineering Reports 12, 33-43.

7. Myszograj, S, Bydałek, F and Płuciennik-Koropczuk, E 2018. Evaluation of seasonal activity of various bacteria in a constructed wetland using AT4 and TTC tests. Desalination and Water Treatment 134, 188-198.

8. Obarska-Pempkowiak, H 2002. Hydrophyte treatment (Oczyszczalnie hydrofitowe). Wydawnictwo Politechniki Gdańskiej, Gdańsk.

9. Obarska-Pempkowiak, $\mathrm{H}$ and Tuszyńska, A 2002. Calculations of hydrophyte deposits in regard to nitrogen removal (Obliczenia złóż hydrofitowych ze względu na usuwanie azotu), V Konferencja NaukowoTechniczna „Oczyszczanie ścieków - nowe trendy”, Zielona Góra.

10. Ozimek, T and Renman, G 1996. Role of helophytes in hydro botanic wastewater treatment plants (Rola heliofitów w oczyszczalniach hydrobotanicznych). II Międzynarodowa Konferencja NaukowoTechniczna, Akademia Rolnicza w Poznaniu, Poznań.

11. Reddy, KR and D'Angelo, EM 1996. Biochemical indicator to evaluate pollutant removal efficiency in constructed wetlands. Vienna.

12. Vohla, C, Alas, R, Nurk, K, Baatz, S and Mander, U 2007. Dynamics of phosphorus, nitrogen and carbon removal in a horizontal subsurface flow constructed wetland. Science of the Total Environment 380, 66-74.

13. Vymazal, J 2011. Plants used in constructed wetlands with horizontal subsurface flow: a review. Hydrobiologia 674, 133-156. 
14. Vymazal, J and Kröpfelová, L 2008. Wastewater Treatment in Constructed Wetlands with Horizontal Sub-Surface Flow. Springer, Environmental Pollution 14.

Editor received the manuscript: 07.06.2020 